\title{
Pemahaman Manajemen Peternak dalam Meningkatkan Produktivitas Usaha Ternak Sapi Potong di Kabupaten Kupang Provinsi Nusa Tenggara Timur
}

\author{
Understanding of Livestock Management in Increasing Business Productivity of Beef Cattle \\ in Kupang District, Province of East Nusa Tenggara
}

\author{
M. M. Sol'uf, M. Krova, dan A. A. Nalle
}

Program Pascasarjana, Program Studi Ilmu Peternakan

Universitas Nusa Cendana, Jl. Adisucipto, Kupang, NTT 85001

*Corresponding Author: medivianimorin@gmail.com

\begin{abstract}
A study has been conducted with the aim to know and understand the complex interactions between various stakeholders and the lever factors in increasing beef cattle productivity in Kupang Regency. Sampling is done in stages. The first stage was to determine four sample districts purposively, the second stage was to determine 40 farmers and 10 traders by snow ball sampling and 6 government officials using the interview approach. The number of key informants depends on the saturation of the information obtained. The software used in this research is Ventana Simulation (Vensim) PLE. The software is used to make a causal diagram. The results showed thatinteraction in beef cattle business can be said that the interaction between actual beef cattle business actors in Kupang Regency is only limited to cattle procurement or sale and purchase of livestock between interests, in this case there are no other interactions that can grow or increase the productivity of beef cattle. An important factor is the production of beef cattle and government services and academic institutions, which means that if these two factors are intervened, the behavior of the system in beef cattle business can change significantly.
\end{abstract}

Key words: management understanding, productivity of beef cattle business

\begin{abstract}
ABSTRAK
Suatu penelitian telah dilakukan dengan tujuan untuk mengetahui dan memahami interaksi kompleks antar berbagai pemangku kepentingan serta faktor-faktor pengungkit dalam meningkatkan produktivitas sapi potong di Kabupaten Kupang. Pengambilan contoh dilakukan secara bertahap. Tahap pertama penentuan empat kecamatan contoh secara purposif, tahap kedua penentuan 40 peternak dan 10 orang pedagang secara snow ball sampling dan 6 orang pejabat pemerintah dengan pendekatan wawancara. Banyaknya informan kunci tergantung pada kejenuhan informasi yang diperoleh. Perangkat lunak yang digunakan dalam penelitian ini adalah Ventana Simulation (Vensim) PLE. Perangkat lunak tersebut digunakan membuat diagram sebab akibat. Hasil penelitian menunjukkan bahwa interaksi dalam usaha ternak sapi potong dapat dikatakan bahwa interaksi antar pelaku aktual usaha sapi potong di wilayah Kabupaten Kupang hanya sebatas pengadaan ternak atau jual beli ternak antar pelaku kepentingan dalam hal ini tidak terdapat interaksi lainnya yang dapat menumbuhkan atau meningkatkan produktivitas ternak sapi potong. Faktor penting yakni produksi sapi potong dan layanan pemerintah dan lembaga akademisi, yang berarti jika dua faktor ini diintervensi maka perilaku sistem dalam usaha ternak sapi potong dapat berubah secara signifikan.
\end{abstract}

Kata kunci: pemahaman manajemen, produktivitas usaha ternak sapi potong

\section{PENDAHULUAN}

Produktivitas usaha ternak sapi potong di wilayah Kabupaten Kupang masih tergolong rendah. Hal ini dilihat dari tingkat kelahiran sapi potong yang masih rendah, tingkat kematian yang tinggi dan bobot badan sapi potong penggemukan yang rendah. Mullik dan Jelantik (2009) menemukan bahwa tingkat kelahiran ternak sapi Bali masih rendah dan bervariasi antara 44,30\% - 98,30\% (rata-rata 70,70\%) dari jumlah betina umur produktif. Selain itu, tingkat mortalitas sapi Bali cukup tinggi yakni $35 \%$ dengan rentangan kematian ternak sangat luas antara 6,12\%-65,5\% (Mullik dan Jelantik, 2009). Nalle (2016) menyatakan bahwa bobot badan sapi potong yang dicapai hanya $0,2-0,4 \mathrm{~kg} /$ ekor dengan rata-rata lama penggemukan 18 bulan sedangkan pertambahan bobot sapi yang optimal untuk sapi Bali dapat mencapai 0,3-0,6 kg/ekor bahkan dapat mencapai 0,87-,1,2 kg/ekor (Moran, 1978) dengan lama penggemukan yang ideal hanya berlangsung 3-4 bulan (Sarwono \& Arianto, 2011) atau 3-6 bulan (Sunarto et al., 2016). 
Produktivitas usaha ternak sapi potong yang rendah menyebabkan produksi ternak yang dihasilkan di kalangan peternak menjadi rendah. Hal ini secara nyata dapat berpengaruh terhadap penerimaan dan keuntungan yang diperoleh sebab harga penjualan ternak sapi potong rendah. Untuk mengatasi produktivitas usaha ternak sapi potong yang rendah berbagai upaya telah dilakukan oleh pemerintah dan lembaga-lembaga terkait. Upaya yang dilakukan berupa bantuan pemberian ternak sapi potong bakalan, pemberian kredit atau bantuan modal dengan bunga relatif rendah, pelatihan teknologi pengolahan pakan, dan pelatihan inseminasi buatan. Namun, pembelajaran dan teknologi yang disosialisasikan masih kurang mendapatkan perhatian dari peternak. Hal ini dikarenakan adanya faktor budaya dan pengetahuan tradisional yang melekat pada peternak. Selain itu, peternak pun belum dilibatkan secara aktif oleh pemerintah dalam menentukan suatu program pengkajian sehingga program pengkajian masih sulit untuk diwujudkan.

Berdasarkan hal ini diketahui bahwa dalam upaya meningkatkan produktivitas usaha sapi potong melibatkan berbagai stakeholder dimana interaksi stakeholder dalam usaha ternak sapi potong saling mempengaruhi antara satu dengan lainnya. Interaksi tersebut membentuk suatu hubungan kausalitas yang dapat menunjukkan faktor-faktor pengungkit atau penentu dalam peningkatan produktivitas usaha sapi potong. Sejauh ini belum ada penelitian mengenai pemahaman manajemen ternak sapi potong dari hulu ke hilir, bagaimana interaksi antar pihak-pihak yang terlibat dalam usaha ternak sapi potong dan apa saja faktor-faktor penting yang dapat digunakan sebagai titik temu untuk menyelesaikan masalah produktivitas ternak sapi potong yang masih tergolong rendah. Oleh karena itu, untuk menjawab masalah ini peneliti melakukan penelitian dengan judul Pemahaman Manajemen Peternak dalam Meningkatkan Produktivitas Usaha Ternak Sapi potong di Kabupaten Kupang Provinsi Nusa Tenggara Timur. Tujuan penelitian ini dilakukan adalah untuk mengetahui dan memahami interaksi kompleks antar berbagai pemangku kepentingan serta faktor-faktor pengungkit dalam meningkatkan produktivitas sapi potong di Kabupaten Kupang Provinsi NTT.

\section{METODE PENELTIAN}

Penelitian ini telah dilakukan selama enam bulan di Kabupaten Kupang. Wilayah Kabupaten terdiri dari 24 kecamatan, dari total kecamatan ini diambil secara purposif 4 kecamatan contoh yakni Kecamatan Amfoang Utara, Amfoang Selatan, Amarasi Barat dan Amarasi Selatan. Populasi dalam penelitian ini terdiri atas pelaku utama dan pelaku pendukung dalam sistem usaha ternak sapi potong yang terdapat di Kabupaten Kupang. Informan kunci pelaku ditentukan melalui pemetaan pelaku dalam usaha sapi potong baik pelaku maupun pendukung. Penentuan informan kunci pelaku menggunakan metode snow ball sampling yakni peternak sebanyak 40 orang dan pedagang sebanyak 10 orang. Selain itu, adapun pemerintah sebanyak enam orang di wilayah Kabupaten Kupang dan dilakukan dengan pendekatan wawancara. Banyaknya informan kunci tergantung pada kejenuhan informasi yang diperoleh. Perangkat lunak yang digunakan dalam penelitian ini adalah Ventana Simulation (Vensim) $P L E$. Perangkat lunak tersebut digunakan membuat diagram sebab akibat.

\section{HASIL DAN PEMBAHASAN}

\section{Pemetaan Pelaku dan Interaksinya dalam Manajemen Usaha Ternak Sapi Potong di Kabupaten Kupang}

Pemetaan pelaku dan interaksinya usaha ternak sapi potong di wilayah Kabupaten Kupang dapat dilihat pada Gambar 1. Interaksi yang terjadi dalam usaha sapi potong merupakan interaksi antara pemangku kepentingan yang terlibat dalam usaha ternak sapi potong. Pada usaha ternak sapi potong pelaku yang terlibat dalam usaha ternak sapi potong yakni peternak, pedagang dan pemerintah dan lembaga akademisi. Peternak sapi potong sebagai pihak penyedia sapi potong. Pedagang sebagai pihak yang menjalankan fungsi pembelian ternak sapi potong yang dijual oleh peternak dan juga pemerintah sebagai penyedia fasilitas sekaligus pemegang kebijakan tertinggi maupun pemerintah sebagai penyedia fasilitas sekaligus pemegang kebijakan tertinggi.

Dalam meningkatkan produktivitas usaha ternak sapi potong pemerintah sebagai pemegang kebijakan tertinggi memberikan berbagai bantuan kepada peternak seperti bibit ternak sapi potong, bibit pakan dan juga penyediaan bantuan maupun 
fasilitas teknologi Inseminasi buatan (IB). Bibit ternak sapi potong dari pemerintah diperoleh dari pasar ternak. Dalam hal ini pemerintah (Dinas Peternakan) membeli ternak sapi potong bakalan dari pasar ternak lalu dilakukan seleksi bibit dan diberikan pada peternak sapi potong yang membutuhkan dalam pengembangan usaha ternaknya. Pemerintah sebagai pemegang kebijakan tertinggi melakukan pemungutan retribusi pada setiap ternak yang dijual oleh peternak sapi potong maupun pedagang. Retribusi tersebut merupakan balas jasa terhadap pemerintah yang telah menyiapkan pasar ternak dan infrastrukturnya.
Selain pemerintah dalam hal ini Dinas peternakan dan UPTD juga terdapat perguruan tinggi dan BPTP sebagai lembaga peneliti dan pengkajian teknologi terkait dengan bidang peternakan. Dimana, lembaga akademisi dan BPTP menemukan dan mengkaji teknologi dan inovasi yang ada dan selanjutnya diabdikan kepada peternak sebagai mitra pengabdian untuk menerapkan teknologi dan inovasi dengan tujuan meningkatkan produktivitas sapi potong. Namun, sejauh ini teknologi dan inovasi yang diberikan baik dari pihak pemerintah Dinas Peternakan maupun pihak akademisi dan lembaga BPTP belum dapat diaplikasi/diterapkan oleh peternak secara optimal.

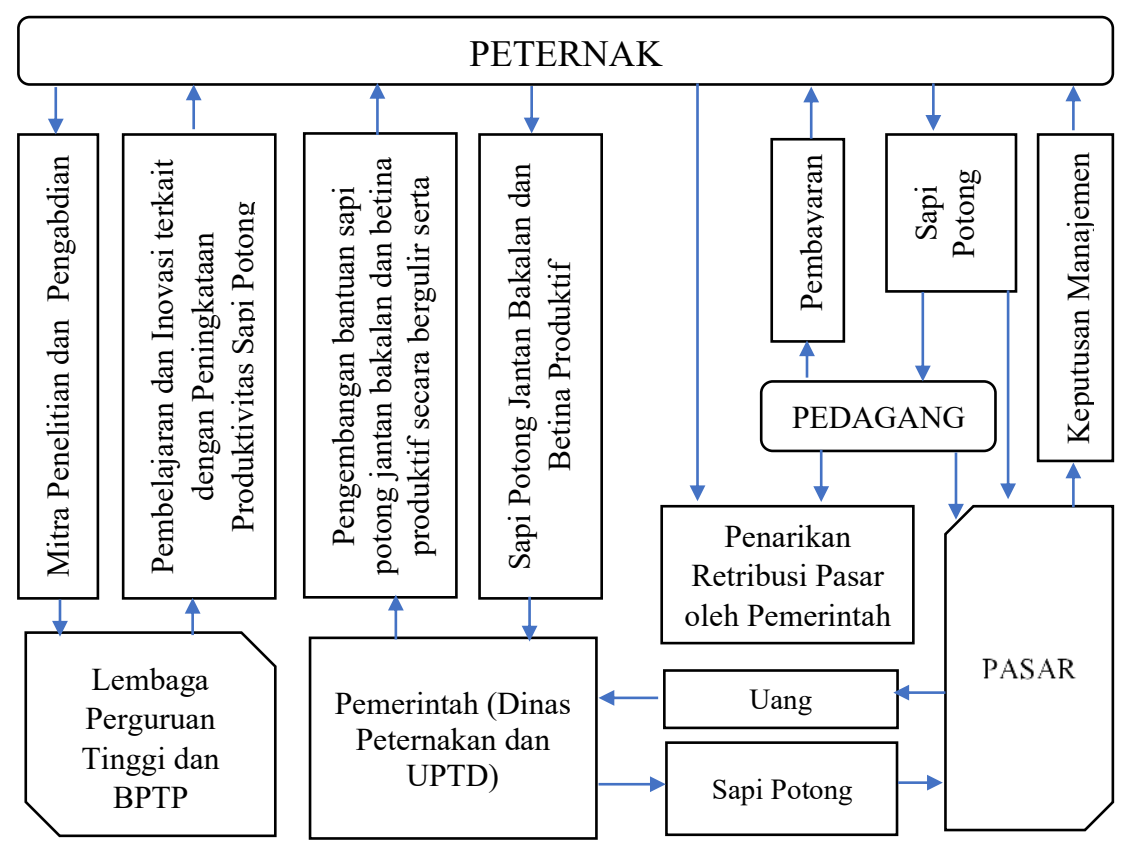

Gambar 1. Model umum peta interaksi pelaku dalam manajemen usaha ternak sapi potong di Kabupaten Kupang

Peternak sapi potong merupakan pelaku yang menyediakan input sapi potong bagi pedagang. Budidaya sapi potong yang dilakukan oleh peternak menghasilkan akan dijual baik melalui pedagang maupun secara langsung dijual ke pasar. Sebagai imbalan atas produk (sapi potong) yang dijual tersebut peternak akan menerima pembayaran. Harga penjualannya juga bervariasi tergantung bobot badan dan penampilan ternak dimana jika ternak sapi mengalami cacat maka harganya lebih murah dibandingkan dengan ternak sapi potong yang sehat variasi harganya dapat mencapai Rp 200.000-500.000/ekor. Dalam memasarkan ternak sapi potong peternak akan mendapatkan informasi pasar. Informasi pasar yang diterima oleh peternak akan menjadi dasar pengambilan keputusan dalam manajemennya.

Berdasarkan pemetaan pelaku dan interaksi dalam usaha ternak sapi potong dapat dikatakan bahwa interaksi antar pelaku aktual usaha sapi potong di wilayah Kabupaten Kupang belum dapat menumbuhkan atau meningkatkan produktivitas ternak sapi potong. Hal ini dikarenakan peternak belum secara optimal mengembangkan maupun menerapkan setiap bantuan yang diberikan oleh pemerintah maupun lembaga akademisi dan BPTP. Pemberian bantuan oleh pemerintah maupun lembaga-lembaga terkait pun masih sebatas pengadaan dan pelaksanaan program yang mana hal ini belum menumbuhkan adanya peningkatan produktivitas sapi potong. 
Kondisi ini menjadi penyebab rendahnya produktivitas sapi potong di wilayah Kabupaten Kupang.

\section{Komponen pembentuk sistem dalam manajemen usaha ternak sapi potong di Kabupaten Kupang}

Dalam dinamika sistem diagram sebab akibat menunjukkan hubungan sebab akibat atas berbagai komponen dalam penerapan ilmu pengetahuan dan teknologi namun dapat mengabaikan manajemen stok sebagai komponen utama dalam system thinking (Sterman 2000; Mirecroft 1982). Tahap ini merupakan bagian dari pemodelan kualitatif dalam dynamic system dan lanjutannya yakni diagram alir, simulasi dan kebijakan yang merupakan tahapan pemodelan kuantitatif (Wolstenholme, 1983).

Pada sub bagian ini dibuat diagram sebab akibat yang memperlihatkan hubungan antara berbagai komponen untuk peningkatan produktivitas sapi potong di Kabupaten Kupang. Pada diagram sebab akibat tanda arah positif menjelaskan adanya hubungan antar variabel dengan arah yang sama sebaliknya tanda arah negatif menjelaskan hubungan antar variabel yang berlawanan. Hasil analisis system thinking menunjukkan bahwa terdapat empat komponen yang menyebabkan terjadinya peningkatan produktivitas ternak sapi potong diantaranya pakan, manajemen pengembangbiakan, teknologi dan inovasi, layanan pemerintah dan lembaga akademisi, serta pasar. Komponen-komponen tersebut dapat dijelaskan sebagai berikut. Komponen pertama yang akan dijelaskan adalah pakan sebagai komponen pokok dalam usaha ternak sapi potong dalam peningkatan produktivitas sapi potong. Semakin meningkat kebutuhan pakan maka akan meningkatkan budidaya pakan. Meningkatnya budidaya pakan menyebabkan produksi pakan di tingkat peternak juga meningkat sehingga persediaan pakan sapi potong pun meningkat. Ketika persediaan pakan di tingkat peternak meningkat maka produktivitas ternak sapi potong pun meningkat sehingga produksi sapi potong di tingkat peternak pun meningkat.

Interaksi antar variabel yang terkait dengan pakan dapat membentuk umpan balik positif (Reinforce-1) yang dapat mendorong pertumbuhan (Gambar 2). Hal ini berarti komponen pakan yang tersedia dalam usaha ternak sapi potong di Kabupaten Kupang dapat mendorong pertumbuhan produktivitas usaha sapi potong baik pembibitan maupun penggemukan.
Ini sejalan dengan pernyataan dari Yusdja dan Ilham (2006) menyatakan bahwa komponen penting yang menunjang usaha peternakan adalah pakan dan air. Pakan dan air merupakan kebutuhan mendasar ternak sebagai makhluk hidup.

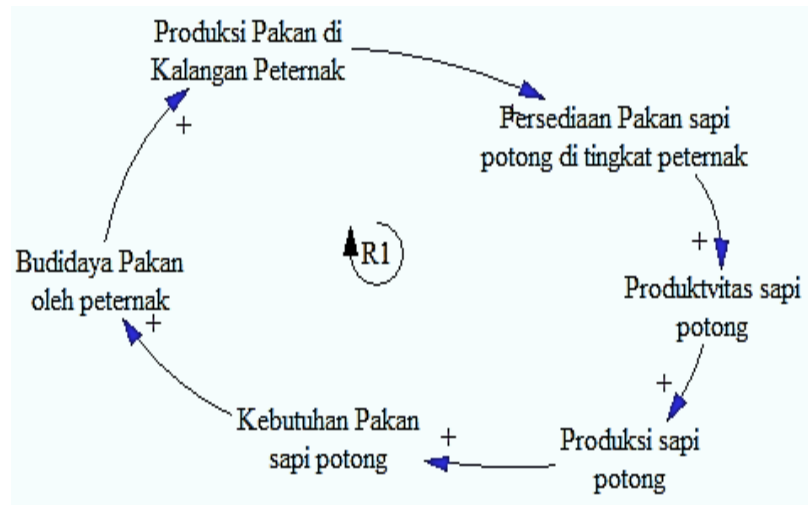

Gambar 2. Komponen Pakan dalam Manajemen Usaha Produksi Ternak Sapi Potong di Kabupaten Kupang

Komponen pertama yang diperlihatkan dari Gambar 2 menunjukkan bahwa pakan yang diberikan peternak pada ternak sapi potong hanya berupa hijauan tidak ada pakan lainnya yakni konsentrat sebagai pakan penguat ternak sapi potong. Hal ini sesuai dengan Rosnah et al. (2004) bahwa penyediaan pakan ternak sapi Bali penggemukan oleh peternak di Kabupaten Kupang masih mengandalkan hijauan legum pohon. Pemberian pakan masih dalam bentuk segar dan belum terbiasa dalam bentuk kering atau dalam formulasi pakan konsentrat.

Rosnah dan Yunus (2018) menyatakan bahwa pemberian pakan sapi potong yang didominasi oleh lamtoro pertambahan bobot badan sapi Bali hanya sebesar 0,28 $\pm 0,259$ $\mathrm{kg}$ /ekor sedangkan Sobang (2005) menjelaskan bahwa penambahan pakan konsentrat sebagai sumber energi dalam pakan sapi Bali penggemukan pada tingkat peternak dapat memberikan pertambahan bobot badan sebesar 0,45-0,5 kg/ekor/hari. Oleh karena itu, pada Gambar 5 ini selain budidaya pakan yang dilakukan oleh peternak juga perlu ditambahkan pakan penguat berupa konsentrat. Sebab pemberian pakan penguat berupa konsentrat dapat memberikan kenaikan pertambahan bobot badan pada ternak dan meningkatkan produksi sapi potong.

Komponen kedua adalah manajemen pengembangbiakan sapi potong (Gambar 3). Pada Gambar 3 dikatehui bahwa meningkatnya 
produktivitas ternak sapi potong menyebakan produksi sapi potong meningkat. Selanjutnya, jika produksi sapi potong meningkat maka produksi, persediaan sapi potong dan manejemen pengembangbiakan pun meningkat. Hal ini menyebabkan presentasi tingkat kelahiran sapi potong sebagai indikator produktivitas sapi potong pun meningkat. Hal ini sejalan dengan pendapat Seiffert (1978) bahwa tingkat reproduksi dan pertumbuhan merupakan indikator produktivitas sapi potong. Interaksi antar variabel yang terkait dengan pakan dapat membentuk umpan balik positif (Reinforce-2) yang dapat mendorong pertumbuhan (Gambar 3).

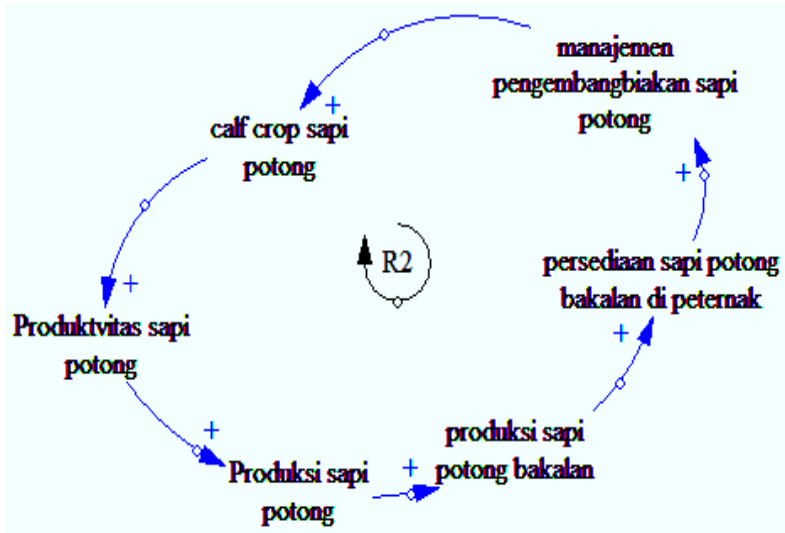

Gambar 3. Komponen Pengembangbiakan Sapi Potong di Kabupaten Kupang
Hal ini berarti komponen pengembangbiakan dalam usaha ternak sapi potong di Kabupaten Kupang dapat mendorong pertumbuhan produktivitas usaha sapi potong baik pembibitan maupun penggemukan

Komponen ketiga ialah inovasi/teknologi dalam usaha ternak sapi potong (Gambar 4). Semakin meningkat produktivitas sapi potong maka akan meningkatkan produksi sapi potong. Tambahan produksi sapi potong di dapat meningkatkan risiko produksi sapi potong dan inisiatif pengadaan teknologi oleh pemerintah maupun lembaga akademisi (melaksanakan tri dharma). Meningkatnya inisiatif pengadaan teknologi oleh pemerintah dan lembaga akademisi menyebabkan keterlibatan, intensitas interaksi, layanan pemerintah dan lembaga akademisi, pengembangan teknologi dan penerapan teknologi oleh peternak pun meningkat sehingga risiko produksi sapi potong peternak kelompok menurun.

Tambahan produksi sapi potong meningkatkan risiko produksi sapi potong peternak sehingga dapat menurunkan produktivitas sapi potong. Interaksi antar berbagai variabel yang terkait dengan teknologi dan inovasi membentuk suatu umpan balik negatif (Balance1) atau menuju keseimbangan. Hal tersebut berarti melalui model teknologi dan inovasi yang ada di wilayah pengembangan sapi potong Kabupaten Kupang dapat mengurangi risiko produksi sapi potong.

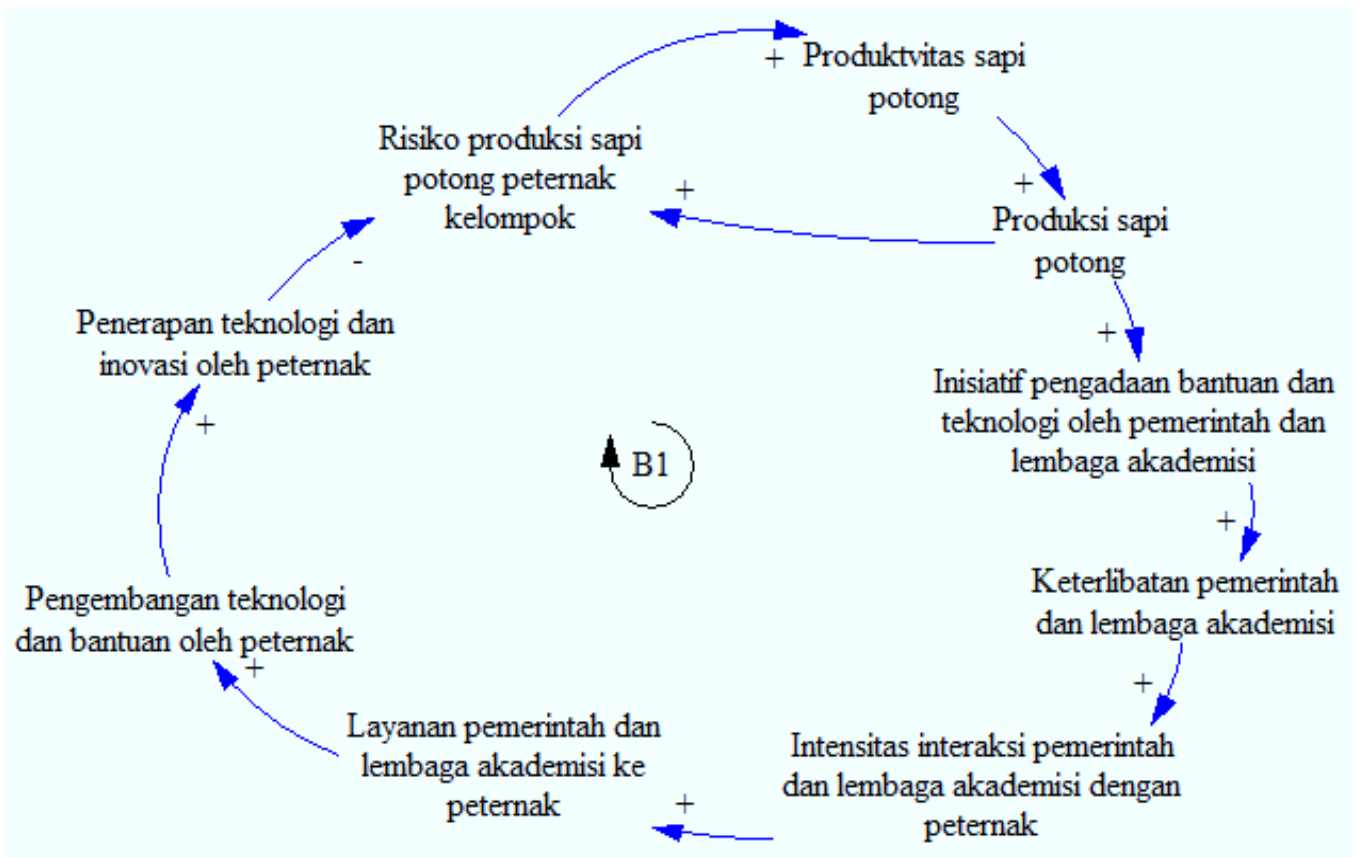

Gambar 4. Komponen layanan pemerintah dan lembaga akademis dalam manajemen usaha produksi ternak sapi potong di Kabupaten Kupang 
Gumbira dan Intan (2004) menyatakan bahwa salah satu pengelolaan risiko agribisnis sehingga usaha agribisnis meningkat ialah berdasarkan aspek teknis. Aspek teknis dapat dilakukan melalui pemanfaatan teknologi misalnya perbaikan bibit, penggunaan alat dan mesin dan lain sebagainya. Hasil survei menunjukkan bahwa berbagai bantuan dari pemerintah maupun pengabdian dari lembaga akademisi telah dilakukan berupa bantuan ternak sapi potong, teknologi IB, teknologi pakan dan lain sebagainya dalam rangka meningkatkan produktivitas sapi potong di Kabupaten Kupang namun belum dapat diadopsi secara optimal oleh peternak sehingga risiko produksi masih meningkat dan produktivitas serta produksi sapi potong menurun. Hal ini sesuai dengan Ratnawaty et al. (2016) bahwa berbagai teknologi hasil penelitian telah banyak dihasilkan, namun sampai kini masih belum semuanya diadopsi petani dan bahkan proses transfer teknologi berjalan lamban.
Oleh karena itu, perlu adanya keterlibatan dan sinergis kerja diantara pihak terkait dimulai dari pusat, provinsi, kabupaten/kota hingga ke tingkat lapangan sehingga risiko produksi dapat diminimalisir dan produktivitas serta produksi sapi potong pun meningkat.

Komponen keempat dalam usaha produksi sapi potong adalah pasar (Gambar 5). Meningkatnya produktivitas sapi potong dapat meningkatkan produksi sapi potong. Selanjutnya meningkatnya produksi sapi potong di tingkat peternak dapat meningkatkan ketersediaan dan penjualan sapi potong di kalangan peternak. Hal ini dapat menambah ketersediaan sapi potong di pedagang pun meningkat sehingga penjualan sapi potong dari pedagang ke pasar pun meningkat. Penjualan sapi potong yang meningkat di pasar menyebabkan ketersediaan sapi potong pun meningkat sehingga menurunkan kebutuhan sapi potong di pasar.

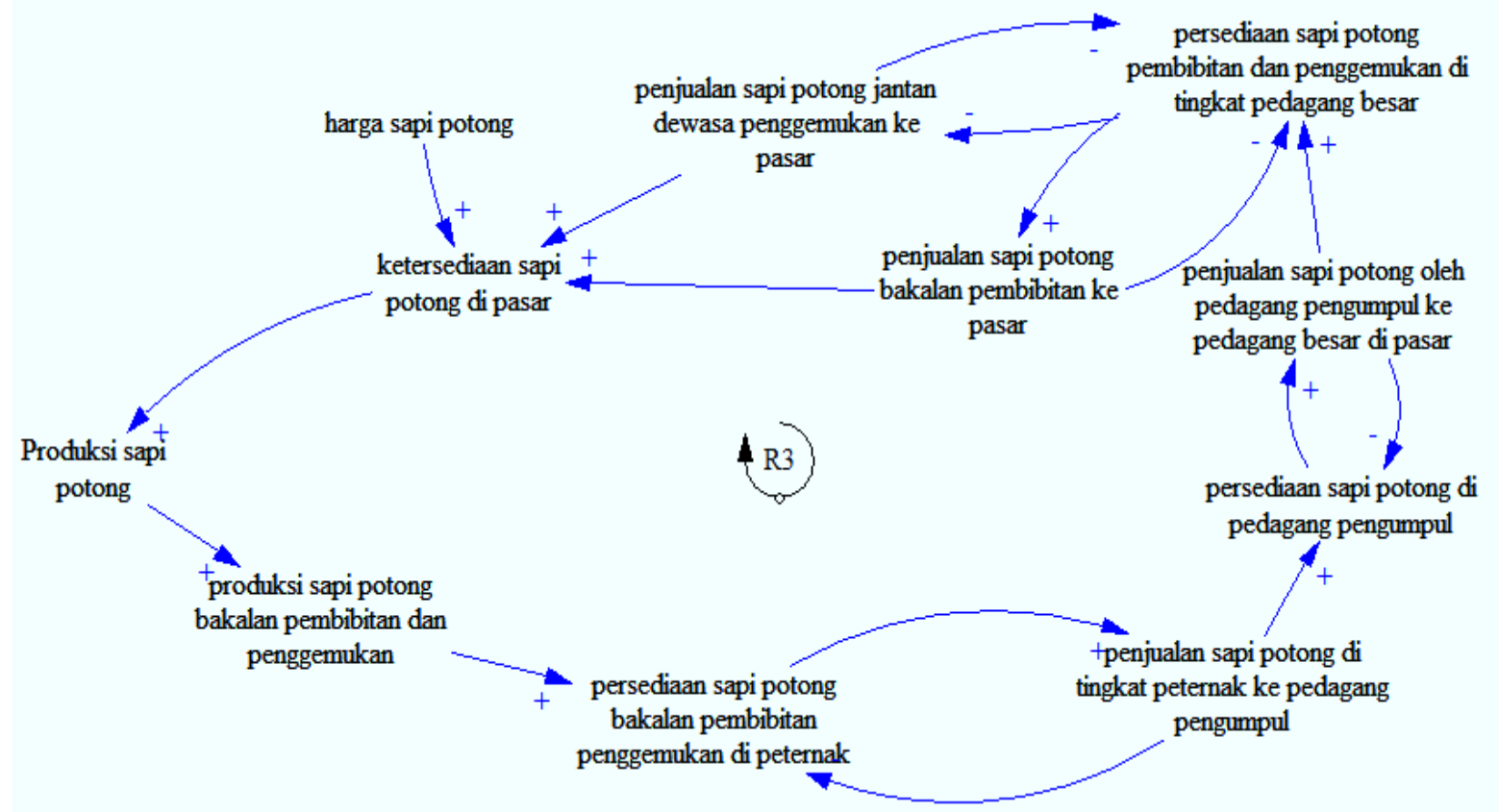

Gambar 5. Komponen pasar dalam manajemen usaha produksi sapi potong di Kabupaten Kupang

Interaksi pasar dalam usaha produksi sapi potong menimbulkan umpan balik positif (Reinforce-3) atau mendorong pertumbuhan. Perilaku pasar akan mendorong peningkatan produktivitas dan produksi sapi potong artinya bahwa dengan adanya pasar produsen/peternak itu sendiri dapat mengetahui besarnya permintaan jumlah sapi potong sehingga dapat memacunya untuk meningkatkan produktivitas dan produksi sapi potong. Nalle et al (2017) bahwa adanya permintaan akan produk sapi potong maupun daging sapi dalam jangka waktu pendek maupun jangka panjang menjadi pendorong bagi semua pihak dalam usaha produksi sapi potong untuk meningkatkan produktivitas dan produksi dengan mengoptimalkan potensi pengembangan ternak sapi potong secara efisien dan berdaya saing.

Berdasarkan semua variabel yang terdapat dalam sistem ternyata ada satu variabel strategis yang sangat kuat pengaruhnya yakni produksi sapi potong dan layanan stakeholder. 
Variabel produksi sapi potong memiliki 8 loops sedangkan layanan stakeholder memiliki 3 loops. Variabel lainnya memiliki loops yang lebih kecil daripada kedua variabel ini. Banyaknya loops mengindikasikan bahwa kedua variabel tersebut sebagai titik strategis atau leverage points dalam usaha ternak sapi potong. Hal ini berarti hanya dengan melakukan intervensi pada kedua variabel tersebut maka perilaku sistem dalam usaha ternak sapi potong dapat berubah secara signifikan.

\section{KESIMPULAN}

Berdasarkan hasil penelitian maka dapat disimpulkan bahwa: 1) Interaksi dalam usaha ternak sapi potong dapat dikatakan bahwa interaksi antar pelaku aktual usaha sapi potong di wilayah Kabupaten Kupang hanya sebatas pengadaan ternak atau jual beli ternak antar pelaku kepentingan dalam hal ini tidak terdapat interaksi lainnya yang dapat menumbuhkan atau meningkatkan produktivitas ternak sapi potong. Hal ini menjadi penyebab produktivitas sapi potong di wilayah Kabupaten Kupang masih tergolong rendah; 2) Dalam usaha ternak sapi potong terdapat dua faktor pengungkit yang menjadi faktor penting yakni produksi sapi potong dan layanan stakeholder, yang berarti jika dua faktor ini diintervensi dengan kebijakan tertentu maka perilaku sistem dalam usaha ternak sapi potong dapat berubah secara signifikan.

Berdasarkan simpulan yang ada maka diharapkan ada penelitian lanjutan dari penelitian ini tentang kebijakan tertentu yang berdasar pada dua faktor pengungkit yakni produksi sapi potong dan layanan stakeholder sehingga peningkatan produktivitas usaha sapi potong dapat tercapai.

\section{DAFTAR PUSTAKA}

Gumbira, E. Said, A. H. Intan. 2004. Manajemen Agribisnis. Edisi Kedua. Penerbit Ghalia Indonesia. Jakarta.

Mirecroft, J.D.W. 1982. Critical Review of Diagrammig Tools for Concetualizing Feedback System Models. Dynamica. Vol. 8. Part 1 Sumbber.

Moran, J.B. 1978. Growth and Carcass Development of Indonesia. Dalam Proc. Sem. Penelitian dan Penunjang Pengemban gan Peternakan.lembaga Penelitian Peternakan Bogor., Bogor.

Mullik, M.L., I.G.N. Jelantik. 2009. Strategi Peningkatan Produktivitas Sapi Bali pada
Sistem Pemeliharaan Ekstensif di Daerah Lahan Kering: Makalah Seminar Nasional Pengembangan Sapi Bali Berkelanjutan dalam Sistem Peternakan Rakyat. Mataram.

Nalle, M.N. 2016. Analisis Efisiensi Teknis Sapi Potong di Kabupaten Kupang Provinsi Nusa Tenggara Timur. Jurnal. Agribisnis Lahan Kering. Vol. 1 (3):57-59.

Nalle, A. A, B. Hartono, B. A. Nugroho, H. D.Utami. 2017. Domestic Resources Cost Analysis of Small-Scale Beef Cattle Farming at Upstream Area of BenainNoelmina Watershed, West Timor, East Nusa Tenggara. Journal of Open Agriculture 2: 417-424.

Ratnawaty, S., P. Amirudin, T. F. Paskalis. 2016. Dukungan Teknologi Perbibitan dan Penggemukan Sapi Potong Melalui Sekolah Lapang di Nusa Tenggara Timur (Kasus Pulau Timor). Prosiding Seminar Nasional Inovasi Teknologi Pertanian Banjarbaru Juli 2016.

Rosnah, U.S., E.D. Sulistijo dan M. Tiro, 2004. Kajian Rendahnya Pemanfaatan Gamal Oleh Peternak Sapi Bali Penggemukan Di Kabupaten Kupang. Laporan Penelitian. Undana, Kupang.

Rosnah, U. S., M. Yunus. 2018. Komposisi Jenis dan Jumlah Pemberian Pakan Ternak Sapi Bali Penggemukan pada Kondisi Peternakan Rakyat. Jurnal Nukleus Peternakan 5 (1): 24-30.

Sarwono, B. dan B. H. Arianto. 2011. Penggemukan Sapi Potong Secara Cepat. Jakarta: Penebar Swadaya

Seiffert, G.W. 1978. Simmulated Selection for Reproduction Rate in Beef Catle. Journal of Animal Science 61. 402-409.

Sobang, Y.U.L. 2005. Karakteristik Sapi Penggemukan Sapi Pola Gaduhan Menurut Zona Agroklimat dan Dampaknya terhadap Pendapatan Petani Di Kabupaten Kupang NTT. Buletin Nutrisi 8 (2): 71-76. ISSN 1410-6191.

Sunarto, E., O.H. Nono., U.R. Lole, Y.L. Henuk. 2016. Kondisi Ekonomi Rumah Tangga Peternak Penggemukan Sapi Potong pada Peternakan 
Rakyat di Kabupaten Kupang. Jurnal Peternakan Indonesia 18 (1): 21-28.

Wolstenholme, E. 1983. Qualitative Quanitative Modelling: The Evolving
Balance. Proceeding on International System Dynamics Conference.
Yusdja dan Ilham. 2006. Arah Kebijakan Pembangunan Peternakan Rakyat. Analisis Kebijakan Pertanian 4 (1):18-36. 